\title{
"Assessing the effect of innovation determinants on macroeconomic development within the EU (28) countries"
}

\begin{tabular}{|c|c|}
\hline AUTHORS & $\begin{array}{l}\text { Dana Kiselakova (D https://orcid.org/0000-0001-5662-5809 } \\
\mathbb{R} \text { http://www.researcherid.com/rid/H-9007-2018 } \\
\text { Beata Sofrankova (D https://orcid.org/0000-0001-9766-0467 } \\
\mathbb{R} \text { http://www.researcherid.com/rid/F-6890-2017 } \\
\text { Erika Onuferova (D https://orcid.org/0000-0001-8529-8843 } \\
\mathbb{R} \text { http://www.researcherid.com/rid/Y-5570-2019 } \\
\text { Veronika Cabinova (D https://orcid.org/0000-0003-4367-3590 } \\
\mathbb{R} \text { http://www.researcherid.com/rid/Y-2092-2019 }\end{array}$ \\
\hline ARTICLE INFO & $\begin{array}{l}\text { Dana Kiselakova, Beata Sofrankova, Erika Onuferova and Veronika Cabinova } \\
\text { (2020). Assessing the effect of innovation determinants on macroeconomic } \\
\text { development within the EU (28) countries. Problems and Perspectives in } \\
\text { Management, 18(2), 277-289. doi:10.21511/ppm.18(2).2020.23 }\end{array}$ \\
\hline DOI & http://dx.doi.org/10.21511/ppm.18(2).2020.23 \\
\hline RELEASED ON & Friday, 19 June 2020 \\
\hline RECEIVED ON & Thursday, 02 April 2020 \\
\hline ACCEPTED ON & Wednesday, 03 June 2020 \\
\hline LICENSE & $\begin{array}{l}(\mathrm{c}) \mathrm{EY} \\
\text { This work is licensed under a Creative Commons Attribution } 4.0 \text { International } \\
\text { License }\end{array}$ \\
\hline JOURNAL & "Problems and Perspectives in Management" \\
\hline ISSN PRINT & $1727-7051$ \\
\hline ISSN ONLINE & $1810-5467$ \\
\hline PUBLISHER & LLC "Consulting Publishing Company "Business Perspectives" \\
\hline FOUNDER & LLC "Consulting Publishing Company "Business Perspectives" \\
\hline
\end{tabular}

NUMBER OF REFERENCES

42
NUMBER OF FIGURES

1

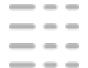

NUMBER OF TABLES

5

(C) The author(s) 2021. This publication is an open access article. 


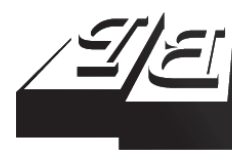

BUSINESS PERSPECTIVES

O

LLC "CPC "Business Perspectives" Hryhorii Skovoroda lane, 10, Sumy, 40022, Ukraine www.businessperspectives.org

Received on: $2^{\text {nd }}$ of April, 2020 Accepted on: $3^{\text {rd }}$ of June, 2020 Published on: $19^{\text {th }}$ of June, 2020

( ) Dana Kiselakova,

Beata Sofrankova, Erika Onuferova,

Veronika Cabinova, 2020

Dana Kiselakova, Associate Professor of Management, Head, Department of Finance, University of Presov in Presov, Presov, Slovak Republic. (Corresponding author)

Beata Sofrankova, Senior Lecturer, Assistant of the Head, Department of Finance, University of Presov in Presov, Presov, Slovak Republic.

Erika Onuferova, Ph.D. Student, Department of Finance, University of Presov in Presov, Presov, Slovak Republic.

Veronika Cabinova, Ph.D. Student, Department of Finance, University of Presov in Presov, Presov, Slovak Republic.
Dana Kiselakova (Slovak Republic), Beata Sofrankova (Slovak Republic), Erika Onuferova (Slovak Republic), Veronika Cabinova (Slovak Republic)

\begin{abstract}
Innovations play an inevitable role in achieving macroeconomic growth of countries, and innovative activity is perceived as a source of sustainable development. This paper's main objective is to explore the impact of innovation determinants on the macroeconomic development of the $\mathrm{EU}$ (28) member countries and identify key problem areas distorting sustainable development and growth of these countries. The research analysis is performed using panel data regression models estimated from 2010 to 2018 . Innovation potential was quantified using selected indicators, such as patent granted, high-tech exports, gross domestic expenditures on $\mathrm{R} \& \mathrm{D}$, government expenditure on education, direct investment, gross fixed capital, and tertiary educational attainment. Such indicators as real GDP per capita and GNI per capita were applied to measure economic growth. The results provide evidence of a statistically significant relationship between innovation and economic growth $(p<0.01)$. Therefore, both research hypotheses were accepted. Based on innovation potential assessment, the statistically significant impact of five indicators were confirmed (high-tech exports, gross domestic expenditure on $\mathrm{R} \& \mathrm{D}$, government expenditure on education, direct investment, and tertiary educational attainment). In this backdrop, the most significant effect was revealed for variable gross domestic expenditure on $\mathrm{R} \& \mathrm{D}$ (0.5343). The findings lead to the conclusion that the EU's and national innovation policies and initiatives should aim to create framework conditions that favor the innovation environment and increase R\&D expenditure to endorse real economic growth.
\end{abstract}

\section{Keywords}

innovation potential, economic growth, $R \& D$ expenditure, panel data regression model

\section{JEL Classification O31, O47, O52}

\section{INTRODUCTION}

As neoclassical theory declares, countries' economic growth is dependent on innovation potential that is conditioned by developing various innovation factors. Following this prerequisite, the innovation is currently considered the major determinant of the country's sustainable performance and global competitiveness in the international economic markets. As reported by Ivanova and Cepel (2018), the process of globalization, the increasing openness, and international integration are the causes of the growing competitiveness of countries, and nations are forced to find key economic sources to achieve a dominant position in the global environment. To ensure the international comparison of countries, it is necessary to define a complex of factors influencing their economic success, productivity, performance, sustainable development, and creating a competitive advantage. The authors emphasize that innovation belongs to key sources and innovation potential of the economy, as a whole, lies in supporting innovation activity at the enterprise level. According to Pukala, Sira, and Vavrek (2018), 
this process is often based on new and unique technologies, contributes to providing durable and sustainable economic development, and is a vector for the development of the entire economy. This is also reflected in gradually increasing expenditure aimed at stimulating the development of innovation and commercialization of effects of research and development work and incurred both by particular countries and on a global scale.

Improving the quality of business environment (Belas, Dvorský, Strnad, Valaskova, \& Çera, 2019) in connection with the sustainable development (Rajnoha, Lesnikova, Stefko, Schmidtova, \& Formanek, 2019), as well as an increasing the innovation potential, belong to the priorities for the EU, which for years has been running a policy of supporting the development in national economies across Europe. In this context, the EU has prepared a sustainable development package section of the 2030 Agenda for Sustainable Development (European Commission, 2015). The core of this agenda is sustainable development goals. One out of the seventeen sustainable development goals set by the EU is to promote inclusive and sustainable industrialization as a powerful driver for improving living standards and ending poverty worldwide. This goal is measured by seven independent indicators: employment in medium and high technology manufacturing sectors, gross domestic expenditure on R\&D, patent applications to the European Patent Office, and R\&D personnel (Grodzicki, 2018). So, these policy interventions at international level confirm the role of science, technology, and innovation in improving the countries' sustainable economic development. In this backdrop, Grabara (2019) proposed a new model of sustainable development evaluation.

\section{LITERATURE REVIEW}

\subsection{Theoretical linkage of the economic growth to innovation activity}

Innovation is considered as a key economic driver of productivity and technology development. Sidorova (2018) claims that constant support of the innovation process at the macro and micro economy levels is the most important determinant of economic development. The overall level of economic sustainability and competitiveness of nations is determined by the degree of state participation and cooperation in the global innovation market. As reported by V. Raghupathi and W. Raghupathi (2017), innovation can initiate economic recovery and ensure the required economic development, leading to sustainable economic growth. Galindo-Martin, Mendez-Picazo, and Castano-Martinez (2019) stated that economic growth is one of the most relevant economic objectives for policymakers. National policymakers pay attention to innovation issues more often, as they are aware that innovation potential development is a key factor in economic growth. In their opinion, it is important to investigate innovation activity in the context of economic development. According to Malik (2020), the process of an economy's development is dependent on innovation in a modern dynamic environment. According to Kowalska, Kovarnik, Hamplova, and Prazak (2018), for sustainable development and to assure competitiveness, every knowledge-based economy applying Industry 4.0 principles is focused on the integration of innovation into economic processes. An almost unanimously accepted issue is that the path to the competitiveness of economies goes through innovation (Ciocanel \& Pavelescu, 2015). However, at the nation's economic level, it is not possible to achieve the required level of competitiveness and growth without the active business entities' participation (Hilkevics \& Hilkevica, 2017).

Many empirical papers are devoted to analyzing the influence of innovation factors on countries' economic development. Balcerzak (2020) stated that the ability to implement technological innovations into the innovation process as soon as possible represents the key factor in the long-term economic growth of countries. In this backdrop, the author analyzed the speed of resource reallocation in the area of innovation on the part of political institutions within the EU member countries from 2000 to 2015. Bistrova and Lace (2016) studied the impact of innovation activity on the economic growth of the EU (28) member countries. Such indicators as R\&D expenses are innovation factors, the number of patents and the num- 
ber of researchers are innovation proxies. Based on the findings, the authors stated that there is a significant relationship between $R \& D$ expenses and GDP growth, as well as labor productivity. In the case of the number of scientists or the number of patents, the statistically significant impact on economic development was not confirmed. Moreover, the authors investigated the impact of scientific productivity on GDP per capita, and the relationship between these variables was proved. V. Raghupathi and W. Raghupathi (2017) analyzed the economic indicators of innovation potential, represented by patents in the technology sector at the national level. Various indicators, namely the ratio of patents owned by foreign residents and the number of patent applications in each branch in the technology sector, represented the innovation potential. Economic indicators included variables such as GDP, gross national income, labor cost, $R \& D$ expenditure, real minimum wage, tax revenue, and education enrollment. Research findings confirmed that countries with low GDP relied on foreign collaboration to improve innovation level; comparison of sectors revealed that government and higher education spend more on $R \& D$ than private and non-profit sectors, and education enrolment contributes to innovation development. Yildirim and Arun (2019) studied the influence of innovation performance on the selected economic indicators, namely FDI, export, R\&D, and GDP per capita. The analysis was realized for the period 2001-2014. The dataset consists of 8 countries with innovation potential at a similar level. According to results, the significant impact was confirmed only in the case of variable FDI. Furthermore, the authors found out the negative dependency between innovation level and export. Haseeb, Kot, Hussain, and Jermsittiparsert (2019) examined the influence of environmental pollution, energy consumption, and economic growth on health expenditures and $\mathrm{R} \& \mathrm{D}$ expenditures in different periods. The research results confirmed a significant positive correlation between the variables analyzed.

\subsection{Innovation potential determinants of the countries}

The development of innovation is a fundamental element for the sustainable economic prosperity of the countries. The economies invest expenditures in innovation activities to be competitive, efficient, resource-sustainable, high-performing, and successful in the global market (Kaynak, Altuntas, \& Dereli, 2017). The economic situation expectancy on national and global levels estimated by economic agents determines the innovation development significantly (Tomaszewski \& Swiadek, 2017).

The level of innovation potential varies from one economy to another. To measure countries' innovation performance is data-intensive, as innovation activities are represented by many different factors that affect nations' innovation performance (Janoskova \& Kral, 2019). A wide range of analyses takes $\mathrm{R} \& \mathrm{D}$ expenditures, gross domestic product (GDP) per capita, average years of tertiary schooling, intellectual property protection, and specialization in the high-tech industry as key determinants of countries' innovation potential (Que \& Zhang, 2018). Another strong debate is related to the outputs of the innovative national capacity represented by patents. However, it is important to emphasize that not every patent is used to create innovation (Proksch, Haberstroh, \& Pinkwart, 2017). $\mathrm{Wu}, \mathrm{Ma}$, and Zhuo (2017) claim several different researchers who analyzed whether the country's innovative level depends only on the investment in R\&D and the intellectual capital or other factors, such as the accumulated technological knowledge, the innovation environment in nation's industrial clusters, and the strength of the relationship between private and public sector. According to Dobrota, Marcu, Siminica, and Netoiu (2019), the $\mathrm{R} \& \mathrm{D}$ is considered a key economic sector to provide products with a marked added value. However, the authors added that innovation performance had included a wider range of variables, not only R\&D expenditures. Mihai and Titan (2014) stated that in innovation development, they play an important role in the education and standard of living. Both elements of innovation performance contribute to generating sustained and competitive economy. As reported by Hadad (2015), economies are forced to create products and processes with increasing economic value-added. However, it is not possible to sustain the innovation environment without public and private sector cooperation. To maintain a competitive innovation is required to invest in $\mathrm{R} \& \mathrm{D}$, to support high-quality research institutions generating new technologies, to share knowledge between the public and private sector, and to ensure their collaboration. 
According to Andrijauskiene and Dumciuviene (2019), the degree of national innovation capacity is influenced not only by global economic development and international network cooperation but also by the country's national economic determinants. Their research aimed to investigate the impact of inward foreign direct investment (IFDI) on NIC using correlation and regression analyses. The analysis was performed within the EU (28) member countries from 2013 to 2016. Based on the results, the authors concluded that human capital and technological inventions belong to the key innovation drivers. Furthermore, it was found out that import and FDI indicators significantly determined employment in knowledge-intensive sectors and positively affect the number of trademark and design applications. Nevertheless, despite the efforts to include marketing and organization innovation as non-technological innovative output, no relationship with the international economic activities (i.e., imports and IFDI) was detected.

The article presented by Brozek (2018) dealt with the innovativeness of the Visegrad Group countries in the context of economic growth using two research methods, particularly statistical data analysis and econometric analysis. GDP was chosen as the explained variable, while the statistically significant variable, with 0.01 significance level, turned out to be the variable unemployed with higher education at 10,000 residents. In contrast, statistically significant variables at 0.05 significance level turned out to be internal $\mathrm{R} \& \mathrm{D}$ expenditure of the enterprise sector at 10,000 residents and internal government spending on R\&D at 10,000 residents. The examined econometric model also included state budget funds for industrial production and technologies. Afonasova, Panfilova, Galichkina, and Slusarczyk (2019) investigated the Russian digital economy in the context of GDP development compared to the EU countries and concluded future development trends. The study tackled five components of the Digital Economic and Society Index based on secondary data from the European Commission. It included the ICT Development Index, the Global Innovation Index (GII), Networked Readiness Index, Share-Households with the Internet, and High-Technology Exports. A cross-country analysis revealed significant differences between Russia and the EU member countries in the area of innovation capacity and innovation level.
To sum up, based on the literature review, many indicators for innovation potential measurement of countries were identified (see Table 1) from a different point of view (science and technology as the most common area). In many cases, authors categorized them into two groups, namely input and output indicators.

Table 1. Overview of the most common indicators used for the country's innovation potential measurement

Source: Authors' elaboration based on Boly, Morel, Assielou, and Camargo (2014), Kasa (2015), Zeng (2017), Wu, Ma, and Zhuo (2017), Zang, Xiong, Lao, and Gao (2018), Halkos and Skoloudis (2018); Andrijauskiene and Dumciuviene (2019)

\begin{tabular}{|c|c|}
\hline Input innovation indicators & $\begin{array}{l}\text { Output innovation } \\
\text { indicators }\end{array}$ \\
\hline R\&D government expenditures & $\begin{array}{l}\text { Patents: absolute number } \\
\text { of patents }\end{array}$ \\
\hline Expenditures on higher education & High-tech exports \\
\hline $\begin{array}{l}\text { Economic openness: foreign } \\
\text { direct investment }\end{array}$ & $\begin{array}{l}\text { Copyrights, trademarks, } \\
\text { design applications }\end{array}$ \\
\hline Private and public investment & $\begin{array}{l}\text { Employment in knowledge- } \\
\text { intensive activities }\end{array}$ \\
\hline $\begin{array}{l}\text { Human resources: a population } \\
\text { with tertiary education }\end{array}$ & $\begin{array}{c}\text { Sales: share of innovative } \\
\text { sales }\end{array}$ \\
\hline $\begin{array}{l}\text { Innovative SMEs collaborating } \\
\text { with others }\end{array}$ & $\begin{array}{c}\text { Knowledge-intensive services } \\
\text { exports }\end{array}$ \\
\hline
\end{tabular}

\section{DATA, METHODOLOGY AND HYPOTHESES}

The paper focused on examining the impact of innovation determinants (expressed by such indicators as a patent granted, high-tech exports, gross domestic expenditures on $R \& D$, government expenditures on education, direct investment, gross fixed capital, and tertiary educational attainment) on macroeconomic development (measured through real GDP per capita and GNI per capita) using the panel data regression analyses. The basic dataset included the EU (28) member states, and research was carried out for the period 2010-2018. Therefore, the total number of observations for this study was 252 - each member state from the European Union (28 in total) was analyzed in each year of the observed period (9 in total). This research aimed to identify key innovation factors influencing the economic growth of the countries analyzed.

Furthermore, the presented article was focused on an in-depth analysis of the EU (28) countries in 
the context of developing selected innovation and macroeconomic indicators. The brief description of the variables is given in Table 2.

Based on the previous theoretical background and stated research aim, the following research task was formulated: Do innovations, represented by the patent granted, high-tech exports, gross domestic expenditure on R\&D, government expenditure on education, direct investment, gross fixed capital and tertiary educational attainment, have a value-enhancing impact on the economic growth of EU (28) member countries?
In accordance with the research aim, the following two hypotheses were formulated:

H1: The selected innovation indicators have a statistically significant impact on real gross domestic product per capita (GDP ${ }_{p c}$ ) development within the EU (28) countries.

H2: The selected innovation indicators have a statistically significant effect on gross net income per capita $\left(G N I_{p c}\right)$ development within the EU (28) countries.

Table 2. Definition of selected variables entering into analyses

Source: Authors' elaboration.

\begin{tabular}{|c|c|c|c|}
\hline Variable & Description & $\begin{array}{l}\text { Unit of } \\
\text { measure }\end{array}$ & $\begin{array}{l}\text { Database } \\
\text { resources }\end{array}$ \\
\hline $\begin{array}{l}\text { Real GDP } \\
\text { per capita }\left(G P_{p c}\right)\end{array}$ & $\begin{array}{l}\text { GDP measures the value of the total final output of goods and services produced } \\
\text { by an economy within a certain period. It includes goods and services that } \\
\text { have markets (or which could have markets) and products produced by general } \\
\text { government and non-profit institutions. }\end{array}$ & EUR per capita & $\begin{array}{l}\text { Eurostat } \\
(2019)\end{array}$ \\
\hline $\begin{array}{l}\text { Gross net income } \\
\text { per capita (GNIpc) }\end{array}$ & $\begin{array}{l}\text { GNI is the sum of value added by all resident producers plus any product taxes } \\
\text { (fewer subsidies) not included in the valuation of output plus net receipts of } \\
\text { primary income (compensation of employees and property income) from abroad. }\end{array}$ & $\begin{array}{l}\text { Current } \\
\text { international } \\
\text { USD (PPP) }\end{array}$ & $\begin{array}{l}\text { World Bank } \\
\text { (2019) }\end{array}$ \\
\hline $\begin{array}{l}\text { European patent } \\
\text { granted } \\
\text { (EPG) }\end{array}$ & $\begin{array}{l}\text { Patent - a product or process that provides a new way of doing something or } \\
\text { offers a new technical solution to a problem. A patent protects the invention } \\
\text { to the patent owner for a limited period, generally, } 20 \text { years based on Patent } \\
\text { Cooperation Treaty procedure. }\end{array}$ & $\begin{array}{l}\text { Number of } \\
\text { patents per } \\
\text { country }\end{array}$ & $\begin{array}{l}\text { European } \\
\text { Patent Office } \\
\text { (2019) }\end{array}$ \\
\hline $\begin{array}{l}\text { High-tech } \\
\text { exports (HTE) }\end{array}$ & $\begin{array}{l}\text { The data shows the share of exports of all high technology products in total } \\
\text { exports. High technology products are defined according to SITC Rev. } 4 \text { as the sum } \\
\text { of the following products: Aerospace, Computers-office machines, Electronics- } \\
\text { telecommunications, Pharmacy, Scientific instruments, Electrical machinery, } \\
\text { Chemistry, Non-electrical machinery, Armament. }\end{array}$ & $\%$ of exports & $\begin{array}{c}\text { Eurostat } \\
(2019)\end{array}$ \\
\hline $\begin{array}{l}\text { Gross domestic } \\
\text { expenditure on } \\
\text { R\&D (GERD) }\end{array}$ & $\begin{array}{l}\text { Research and experimental development (R\&D) comprise creative work } \\
\text { undertaken systematically to increase the stock of knowledge, including } \\
\text { knowledge of man, culture, and society, and the use of this stock of knowledge to } \\
\text { devise new applications. }\end{array}$ & $\%$ of GDP & $\begin{array}{l}\text { Eurostat } \\
(2019)\end{array}$ \\
\hline $\begin{array}{l}\text { Government } \\
\text { expenditure on } \\
\text { education (GEE) }\end{array}$ & $\begin{array}{l}\text { General government expenditure on education (current, capital, and transfers) is } \\
\text { expressed as a percentage of total general government expenditure on all sectors } \\
\text { (including health, education, social services, etc.). It includes expenditure funded } \\
\text { by transfers from international sources to the government. }\end{array}$ & $\begin{array}{l}\text { \% of } \\
\text { government } \\
\text { expenditure }\end{array}$ & $\begin{array}{l}\text { World Bank } \\
\text { (2019) }\end{array}$ \\
\hline $\begin{array}{l}\text { Direct investment } \\
\text { in the reporting } \\
\text { economy (DI) }\end{array}$ & $\begin{array}{l}\text { Direct investment (DI) is a category of investment that reflects the objective of } \\
\text { establishing a lasting interest by a resident enterprise in one economy (direct } \\
\text { investor) in an enterprise (direct investment enterprise) that is resident in an } \\
\text { economy other than that of the direct investor. }\end{array}$ & $\begin{array}{c}\text { Annual data, } \% \\
\text { of GDP }\end{array}$ & $\begin{array}{l}\text { Eurostat } \\
(2019)\end{array}$ \\
\hline $\begin{array}{l}\text { Gross fixed capital } \\
\text { formation (GFC) }\end{array}$ & $\begin{array}{l}\text { Gross fixed capital formation consists of resident producers' acquisitions, fewer } \\
\text { disposals, fixed tangible or intangible assets. This covers, in particular, machinery } \\
\text { and equipment, vehicles, dwellings, and other buildings. }\end{array}$ & $\begin{array}{l}\text { At current } \\
\text { prices (million } \\
\text { euro) }\end{array}$ & $\begin{array}{c}\text { Eurostat } \\
(2019)\end{array}$ \\
\hline $\begin{array}{l}\text { Tertiary } \\
\text { educational } \\
\text { attainment (TEA) }\end{array}$ & $\begin{array}{l}\text { The indicator measures the share of the population aged 30-34 who have } \\
\text { successfully completed tertiary studies (e.g., university, higher technical } \\
\text { institution, etc.). This educational attainment refers to ISCED (International } \\
\text { Standard Classification of Education). }\end{array}$ & $\begin{array}{c}\% \text { of population } \\
\text { aged } 30-34\end{array}$ & $\begin{array}{l}\text { Eurostat } \\
(2019)\end{array}$ \\
\hline
\end{tabular}


To meet the goals of this research study, panel data regression analysis presenting one of the multidimensional statistical methods was performed. To analyze the relationship among variables, a Fixed Effects Model (FEM) was used. The basic panel data regression model can be expressed by the following model (Greene, 2003):

$$
\begin{aligned}
& y_{i t}=\beta_{1} x_{i t 1}+\beta_{2} x_{i t 2}+\ldots \\
& +\beta_{k} x_{i t k}+\alpha_{1} z_{i 1}+\alpha_{2} z_{i 2}+\ldots \\
& +\alpha_{q} z_{i q}+u_{i t},
\end{aligned}
$$

where $y_{i t}-i^{\text {th }}$ value of variable $Y$ in the basic file, $X_{1}-X_{k}$ - explanatory variables, $i-$ cross-sectional dimension, $t$ - time dimension, $\beta_{0}$ - intersection of the $y$-axis with the regression line, $Z_{1}-Z_{q}-$ individual effects, $\beta_{n}$ - regression coefficient in the basic file, $u_{i t}-i^{\text {th }}$ random error of variable.

Within panel data regression model, the Fixed Effects Model was used. If the individual effects of $Z_{1}$ and $Z_{q}$ are unobservable but correlated with explanatory variables, then the FEM model has the following form:

$$
\begin{aligned}
& y_{i t}=\alpha_{i}+\beta_{1} x_{i t 1}+\beta_{2} x_{i t 2}+\ldots \\
& +\beta_{k} x_{i t k}+u_{i t},
\end{aligned}
$$

where $\alpha_{i}$ - specific constant for each cross-sectional unit.

\section{EMPIRICAL RESULTS}

The following section of the presented paper is devoted to an in-depth analysis of selected input indicators development divided into two groups - macroeconomic indicators evaluating economic growth and indicators focusing on the assessment of innovation potential of EU (28) member countries for the years 2010-2018.

\subsection{Assessment of the selected macroeconomic indicators}

When evaluating the development of both selected macroeconomic indicators (GDP $\mathrm{pc}_{\mathrm{pc}}$ and $\mathrm{GNI}_{\mathrm{pc}}$ ) for the period 2010-2018, an increasing economic trend is visible (see Figure 1). The average values of the $\mathrm{GNI}_{\mathrm{pc}}$ indicator reached higher values than the average of the GDP ${ }_{p c}$ indicator in the EU member countries every year.

The GDP ${ }_{\mathrm{pc}}$ indicator ranged from the lowest average value of EUR 24,138 in 2010 to the highest average value reached in 2018. This development represents an increase of about $13.32 \%$ for the period analyzed. The decrease in average GDP ${ }_{p c}$ value was recorded only in 2012 (approximately 1\%), while the most significant year-to-year growth was indicated in 2015 (an increase of about 3.48\%). The decrease of average GDP ${ }_{p c}$ value was recorded only in 2012 (approximately 1\%), while the most significant year-to-year growth was indicated in 2015 (an increase of about 3.48\%). On average, the year-on-year increase was indicated between $2 \%$ and $2.5 \%$. The similar development of the EU member countries was also ascertained in the case of the $\mathrm{GNI}_{\mathrm{pc}}$. The indicator reached the lowest average value in 2010 (USD 31,110), with an increase of 34\% in 2018 (USD 41,714). The year-on-year increase assessment revealed that the biggest change of $6.42 \%$ was achieved in 2017, while in 2012 year-

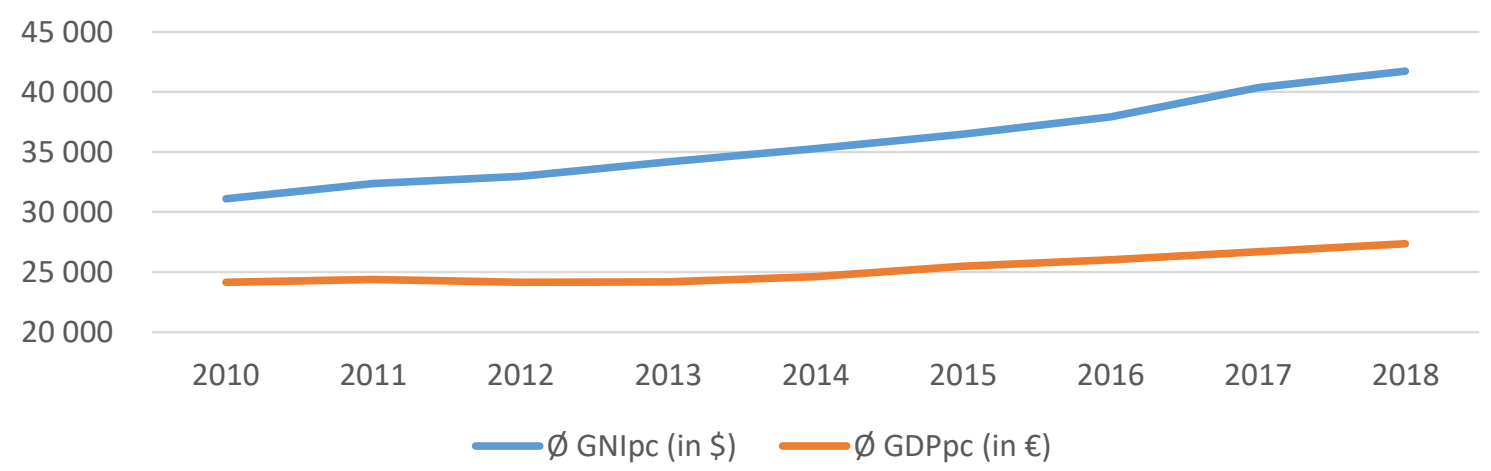

Figure 1. The analysis of the $\mathrm{GDP}_{\mathrm{pc}}$ and $\mathrm{GNI}_{\mathrm{pc}}$ average values development in the EU (28) countries 
on-year increase of only about $1.86 \%$ was reached. The average year-on-year change ranged from $3.5 \%$ to $4 \%$. Based on the EU (28) countries comparison during the period analyzed, on average, Bulgaria achieved the worst results (in the case of both indicators mentioned above). On the other hand, Luxembourg was identified as the EU leader with the best macroeconomic development.

\subsection{Assessment of the selected innovation indicators}

The next subsection was focused on an in-depth development analysis of the innovation variables used. The basic output of descriptive statistics within the selected variables is presented in Table 3. The total number of observations for this study was 252 - each member state from the European Union (28 in total) was analyzed in each year of the observed period (9 in total).

Over the period analyzed, 1,280 patents per year, on average, were registered in the EU countries (28), while 997 were granted in 2010, and by 2018, their number increased by almost $88 \%$ (1,874 patents). Based on trend analysis, the most significant year-on-year growth was revealed in 2016 (about $34 \%$ ), which presents about 398 patents more compared to 2015. On the other hand, a yearon-year decrease of about $2.21 \%$ was recorded in 2014 , and a slight decrease in the average number of patents was indicated in $2012(0.09 \%)$. When evaluating the EPG indicator, there were significant differences between the European countries. Furthermore, only 8 countries achieved better results than the European average (AT, SE, NL, UK, IT, FR, DE). The leading position in the number of patents belonged to Germany. This country regis- tered 15,379 patents during $2010-2018$ on average, and in 2018 it was registered up to 20,804 patents. The lowest average annual number of patents was found in Croatia and Romania (7 patents).

The HTE indicator took unstable development during the analyzed period when reaching its highest level in 2010 (12.3\% of European exports) and gradually declining to the lowest value in 2014 (11.4\%). The most significant year-on-year decrease of $4.88 \%$ was observed in 2011, while the most significant year-on-year change of more than $6 \%$ was recorded in 2015. In 2018, on average, high-tech exports accounted for $11.90 \%$ of total exports in the EU (28) countries, and the same results were also achieved in 2016. The highest share of hightech exports on overall export was achieved by Malta (from 2011 to 2015) and Ireland (from 2015 to 2018). On the contrary, the lowest share of $3 \%$ to $4 \%$ was recorded by Portugal and Greece (only in 2013 and 2017). The average value of this indicator was ranged at a level of $11.8 \%$, whereby 13 European countries performed better than the EU average, and 15 countries were assigned below the EU average.

One of the other innovation indicators analyzed was gross domestic expenditure on $\mathrm{R} \& \mathrm{D}$, which is expressed as a percentage of GDP. Looking at the development trend of this indicator for the EU (28) countries, the average values ranged from $1.51 \%$ (in 2011) to $1.62 \%$ (in 2018). The most significant increase of $4.64 \%$ occurred in 2012, and the rate of growth had been growing by $2.5 \%$ year-on-year in the last 2 years. The highest year-on-year decline was recorded in 2016 (4.35\%). During 2011-2014, Finland was identified as a leader in the assessment of an indicator mentioned above (at the level

Table 3. Descriptive statistics of the selected innovation indicators

\begin{tabular}{|c|c|c|c|c|c|c|c|}
\hline $\begin{array}{c}\text { Descriptive } \\
\text { statistics }\end{array}$ & EPG & HTE & GERD & GEE & DI & GFC & TEA \\
\hline Mean & $1,279.96$ & 11.84 & 1.58 & 11.64 & 26.76 & $101,020.06$ & 38.98 \\
\hline Median & 93.50 & 9.80 & 1.34 & 11.52 & 2.50 & $39,169.60$ & 41.20 \\
\hline Std. deviation & $3,072.60$ & 6.73 & 0.87 & 2.40 & 141.72 & $151,586.57$ & 9.70 \\
\hline Skewness & 4.10 & 1.01 & 0.61 & 0.58 & 5.43 & 2.10 & -0.16 \\
\hline Kurtosis & 18.38 & 0.68 & -0.79 & -0.02 & 46.64 & 3.66 & -0.95 \\
\hline Minimum & 1.00 & 2.70 & 0.38 & 7.54 & -722.20 & $1,225.60$ & 18.30 \\
\hline Maximum & $20,804.00$ & 34.70 & 3.71 & 18.90 & $1,295.60$ & $707,719.00$ & 58.70 \\
\hline Percentiles 25 & 18.50 & 6.45 & 0.84 & 9.67 & 1.20 & $8,916.95$ & 31.05 \\
\hline Percentiles 75 & $1,097.50$ & 15.75 & 2.21 & 13.07 & 5.35 & $99,140.50$ & 45.75 \\
\hline
\end{tabular}


of $3.71 \%$ ), whereby, since 2015, it was replaced by Sweden (GERD reached more than 3\% of GDP). Cyprus and Romania belonged to the countries with the lowest GERD values. When comparing individual countries, up to 18 countries performed better results than the EU average (1.58\%).

In 2018, the indicator of government expenditure on education (GEE) reached the highest average of $12.07 \%$. This result was achieved by a gradual yearon-year increase by around $1 \%$ on average since 2010 (11.24\%). Besides, the decreasing trend of expenditure on education was recorded twice during the period analyzed, and it is in $2014(0.68 \%)$ and 2015 (0.17\%). Malta (16.14\%), Cyprus (16.05\%), and Sweden (15.08\%) belonged to the EU countries (28) with the highest average share of government expenditure on education. On the other hand, the lowest share of expenditure, as indicated in the case of Greece (7.74\%), Italy (8.14\%), and Romania (9.07\%). An average value of the mentioned indicator was ranged at the level of $11.64 \%$ over the whole period.

The indicator of DI (Direct Investment in the Reporting Economy) achieved $26.8 \%$ of GDP within the EU countries (28) during 2010-2018 on average. Luxembourg recorded the highest DI, while Austria reached the lowest value. Furthermore, the analysis showed that only 4 countries achieved better results than the EU average (IE, MT, CY, and LU), and all other European countries recorded significantly lower direct investment. Furthermore, the most significant year-on-year change was revealed in 2015 (about 36.4\%).

The GFC (Gross Fixed Capital Formation) indicator development recorded a positive trend, rising from EUR 91,915 million (in 2010) to EUR 115,897 million (in 2018) on the EU (28) average. On the other hand, the year-on-year decrease was revealed in 2013 (1.49\%) and 2012 (0.30\%). Germany was identified as a leader among the European countries. Over the period analyzed, this country generated gross fixed capital at a value of EUR 596,651 million on average. This is followed by France, which generated gross fixed capital of average value at EUR 480,150 million, and third place was taken by the United Kingdom (EUR 367,587 million). On the other hand, the lowest value of this indicator was recorded by Malta, when gross fixed capital amounted to EUR 1,804 million. Based on the findings, it can be stated that only six countries achieved better results than the EU average.

The last indicator of innovation assessment was tertiary educational attainment, expressed as a \% of the population aged 30-34 as the only one of the selected indicators achieved an increasing trend during the analyzed period. The biggest year-onyear change was revealed in 2014 (4.21\%), while the lowest change was identified in the last analyzed year (1.66\%). The best average values in the case of TEA indicator were achieved by Ireland (53.6\%), Lithuania (52.7\%), Luxembourg (51.7\%), and Sweden (49.2\%). On the contrary, the worst ranks in the ranking were placed by Romania (23.4\%), Italy (23.9\%), and Croatia (28.0\%). About this indicator, the average of the EU countries achieved a value at the $39 \%$ level, whereby 16 countries were arranged above the EU average.

\subsection{Regression analysis results}

The next subsection of the presented paper was devoted to the quantitative evaluation of the selected innovation indicators (independent variables) impact on macroeconomic development (dependent variables) of the $\mathrm{EU}$ (28) member countries during the period 2010-2018. Panel data regression analyses were made. The attention was focused on examining the relationship between GDP ${ }_{\mathrm{pc}}, \mathrm{GNI}_{\mathrm{pc}}$, and innovation indicators (EPG, HTE, GERD, GEE, DI, GFC, and TEA). The results of the regression analysis are presented in Tables 4 and 5.

Based on the analysis of the regression model appropriateness (Table 4), the regression equation is appropriate with regard to Fisher's test criterion at the selected significance level $\alpha=5 \%(p=$ 0.0000 ). The coefficient of determination (adjusted $R^{2}$ ), which explains the variability of the dependent variable $\left(\mathrm{GDP}_{\mathrm{pc}}\right)$, achieved a $61.02 \%$ value. The regression analysis confirmed the statistically significant impact ( $p=0.0000)$ of five innovation indicators (HTE, GERD, GEE, DI, and TEA) on the macroeconomic development of the EU (28) countries (measured by $\mathrm{GDP}_{\mathrm{pc}}$ ) over the period analyzed. Moreover, the findings showed that four innovation determinants (HTE, GERD, DI, and TEA) influenced the GDP ${ }_{\mathrm{pc}}$ positively, while GEE indicator has an opposite impact (-0.1967). The most sig- 
Table 4. Panel data regression analysis between $\mathrm{GDP}_{\mathrm{pc}}$ and innovation indicators

Source: Authors' results.

Panel data regression summary for dependent variable: GDP

Fixed Effects Model (FEM) $R=.0 .6665 ; R^{2}=.0 .6630$; adjusted $R^{2}=.0 .6102$;

$F(34.217)=12.5548 ; p<0.0000$; std. error of estimate: 0.6243

$N=252$ observations included 28 cross-sectional units; time series length $=9$

\begin{tabular}{l|c|c|c|c}
\hline & Coefficient & Std. err. & t-ratio & $p$-value \\
\hline Intercept & 0.0000 & 0.0393 & 0.0000 & 1.0000 \\
EPG & -0.0464 & 0.0892 & -0.5195 & 0.60392 \\
HTE & $0.2432^{*}$ & $0.0487^{*}$ & $4.9985^{*}$ & 0.00001 \\
GERD & $0.5015^{*}$ & $0.0508^{*}$ & $0.8699^{*}$ & 0.00001 \\
\hline GEE & $-0.1967^{*}$ & $0.057^{*}$ & $-3.7330^{*}$ & 0.00024 \\
\hline DI & $0.3013^{*}$ & $0.0476^{*}$ & $6.3284^{*}$ & 0.00001 \\
GFC & 0.0526 & 0.0867 & 0.6065 & 0.54485 \\
TEA & $0.3676^{*}$ & $0.0530^{*}$ & $6.9427^{*}$ & 0.00001 \\
\hline
\end{tabular}

Note: ${ }^{*}$ indicates significance at 0.05 level.

nificant impact on economic growth (GDP ${ }_{\mathrm{pc}}$ ) was indicated for variable GERD (0.5015). The following panel data regression model can express the relations between variables:

$$
\begin{aligned}
& G D P_{p c}=0.2432 H T E+0.5015 G E R D- \\
& -0.1967 G E E+0.3013 D I+0.3676 T E A .
\end{aligned}
$$

The second regression analysis led to the following findings. The regression equation is appropriate with regard to Fisher's test criterion at the significance level of $\alpha=5 \%(p=0.0000)$. The coefficient of determination (adjusted $R^{2}$ ), which explains the variability of the dependent variable $\left(\mathrm{GNI}_{\mathrm{pc}}\right)$, achieved $70.33 \%$. In this case, the regression analysis also confirmed the statistically significant impact $(p=0.0000)$ of five innovation indicators (HTE, GERD, GEE, DI, and
TEA) on macroeconomic development of the EU (28) countries (measured by $\mathrm{GNI}_{\mathrm{pc}}$ ) during the years 2010-2018. By comparing the independent variables in the regression model, it was found out that $\mathrm{GNI}_{\mathrm{pc}}$ (the second indicator reflected economic growth) was significantly determined by four innovation determinants (HTE, GERD, $D I$, and TEA) with positive impact (strong medium impact). On the other hand, GEE affected GNI development negatively (-0.1357). The most significant impact on economic growth measured by $\mathrm{GNI}_{\mathrm{pc}}$ was revealed in the case of variable GERD (0.5677). Based on the regression analysis results, the following regression model can be formulated:

$$
\begin{aligned}
& G N I_{p c}=0.2693 H T E+0.5677 G E R D- \\
& -0.1357 G E E+0.2109 D I+0.2844 T E A .
\end{aligned}
$$

Table 5. Panel data regression analysis between $\mathrm{GNI}_{\mathrm{pc}}$ and innovation indicators

Source: Authors' results.

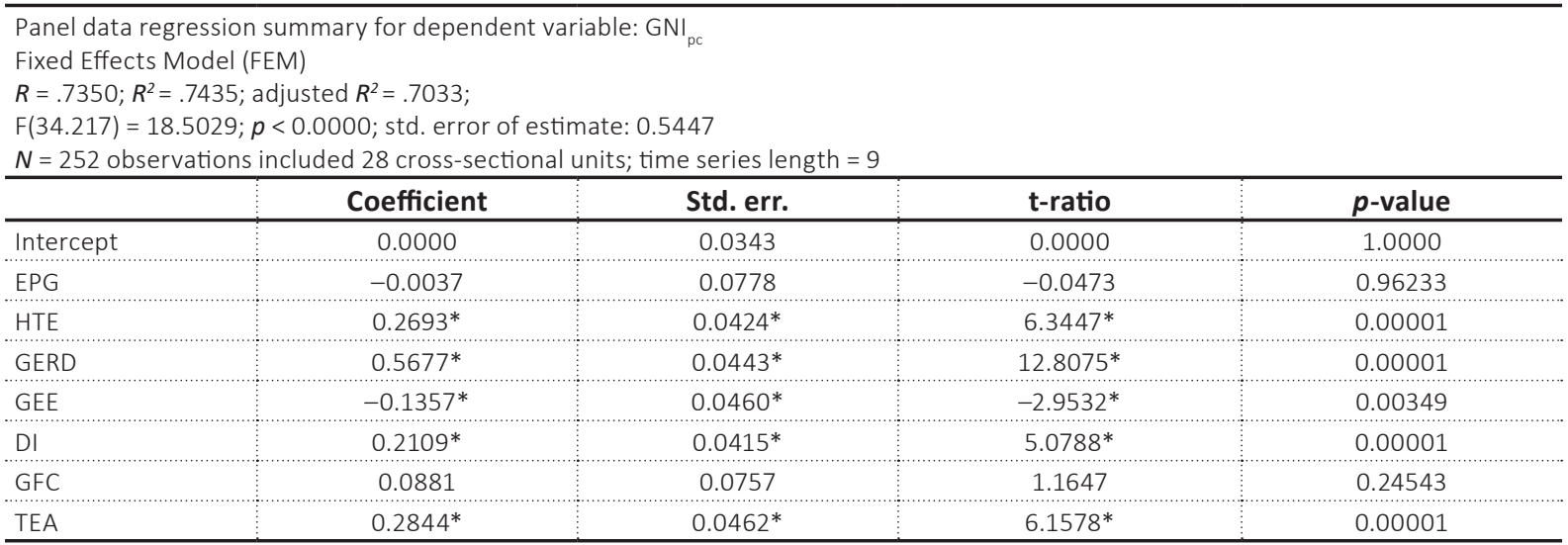

Note: * indicates significance at 0.05 level. 


\section{DISCUSSION}

Many research papers are devoted to examining innovation in relation to nations' economic growth. Risso and Carrera (2019) investigated the correlation between income inequality, innovation, and economic growth using 74 countries' data. Based on the pairwise causality tests, the authors revealed bidirectional causality between GDP per capita and R\&D. As reported by Zhao (2018), innovation strategies are an essential driver of economic development. The influence of technological innovation on economic growth was estimated. Moreover, the author focused on identifying key innovation factors using econometric models. Empirical findings showed a positive relationship between variables analyzed, but R\&D expenditure and patents are correlated with economic growth at a significant level. The study presented by Maharramov, Sariyev, Shamilova, and Rasulova (2018) aimed to determine the specifics, directions of development at the international level of innovative national business in accordance with the country's national economic development strategy. In the article, the development stages of national business were reviewed, and linear double-regression dependencies have been established between the indicators that determine GDP and innovation levels. One of the sights of the article was the justification of the causal relationship between the development of human capital, science, and innovation, which is formed as a "law of human capital" and defined as a mechanism of its functioning. As reported by Baneliené, Melnikas, Strazdas, and Toločka (2018), the ongoing economic changes are related to the issue of innovation activities improvements. The authors focused on evaluating the relationship between $R \& D$ expenditure and economic development in the EU mem- ber states using global indexes, such as Global Innovation Index, EU Innovation Scoreboard, Competitive Industrial Performance Index, Global Competitiveness Index, Knowledge Economy Index, and Innovation Capacity Index. The authors suggested that new models examine the relationship between innovation potential and economic prosperity. To sum up, many research papers contained macroeconomic models to analyze the relationship between countries' innovation and economic growth. However, many researchers investigated the innovation level only through aggregate innovation indices or observed the innovation potential only from the point of view of technological progress. In this backdrop, the research included less frequented innovation determinants, such as government expenditure on education, direct investment, or tertiary educational attainment.

At the close of the discussion section, the limitations of this research paper are stated. According to the findings in this research, the number of innovation and economic indicators used is insufficient to formulate general recommendations. The validity of this study results for the EU (28) member countries is the limitation. It is not quite correct to generalize research finding for all countries in consideration of political interventions in the area of national innovation strategies, as well as the economic disparities among individual countries. For the future research, it is important to investigate other innovation incentives concerning the research in a private sector requiring adequate human resources; to explore the level of cross-border activities to support transfers of information; to analyze the environment for investment in sectors that support the development of digital technology and information; to evaluate the usage of foreign capital for R\&D.

\section{CONCLUSION}

The economic prosperity of the countries, not only in the European region, is determined by innovation activities. To reveal the influence of selected innovation determinants on the macroeconomic development of the EU (28) member countries, a panel data regression model (FEM) was applied.

Within both regression analyses performed, regression equations were appropriate with regard to Fisher's test criterion at the selected significance level $\alpha=5 \%(p=0.0000)$. The regression analysis confirmed the statistically significant impact $(p=0.0000)$ of five innovation indicators (HTE, GERD, GEE, 
DI, and TEA) on the macroeconomic development of the EU (28) countries measured by GDP and GNI $_{\mathrm{pc}}$ over the period analyzed. In the case of four innovation determinants (HTE, GERD, DI, and TEA) were revealed the positive impact on economic growth (0.3432; on average). Moreover, findings showed that GEE (government expenditure on education) indicator influenced the economic development negatively ( -0.1662 ; on average). By comparison of all innovation determinants (independent variables), the most significant impact on economic growth (dependent variables) was indicated for variable GERD (0.5343; on average). Based on research results, both research hypotheses were accepted, so there is a statistically significant impact of the selected innovation indicators on macroeconomic development within the EU (28) countries over the period analyzed.

Besides, special attention was paid to evaluating the innovation factors in the EU member countries. It was revealed that all innovation determinants achieved unstable development during the analyzed years, except for the tertiary educational attainment indicator (a growing trend every year). However, despite the unstable development, an increase in the EU countries' innovation potential had been recorded for 2010-2018. When comparing the individual EU countries, other important findings were obtained. Considering all innovation factors used, Germany, Luxembourg, Malta, Finland, and Ireland belonged to the best-performed countries. According to innovation potential assessment, Romania, Portugal, Greece, Cyprus, and Croatia were placed in the worst ranks.

Based on all the presented findings, the following conclusions can be formulated. Knowledge, R\&D expenditure, investment, high-tech exports, and innovation play a crucial role in the countries to achieve competitive advantage leading to sustainable economic growth. The strategies framework for integrating the research, education, and innovation should be designed at high national and international levels. The government of countries should ensure an increase in financial resources for the effective operation of strategic innovation systems. The innovation requires looking at problems from a new perspective, and the modern education system should be connected to innovation drivers, such as new technological and digital applications. Moreover, the interactive and dynamic connection between the research and the real economic market is inevitable. Furthermore, the maximum possible synergy between the public and private sectors represents fundamental requirements.

\section{AUTHOR CONTRIBUTIONS}

Conceptualization: Beata Sofrankova.

Data curation: Veronika Cabinova.

Formal analysis: Erika Onuferova.

Funding acquisition: Dana Kiselakova.

Investigation: Dana Kiselakova, Veronika Cabinova.

Methodology: Beata Sofrankova, Erika Onuferova.

Project administration: Dana Kiselakova.

Resources: Erika Onuferova, Veronika Cabinova.

Software: Beata Sofrankova, Veronika Cabinova.

Supervision: Dana Kiselakova, Beata Sofrankova.

Validation: Erika Onuferova.

Visualization: Erika Onuferova, Veronika Cabinova.

Writing - original draft: Dana Kiselakova, Beata Sofrankova.

Writing - review \& editing: Dana Kiselakova, Beata Sofrankova, Erika Onuferova, Veronika Cabinova.

\section{ACKNOWLEDGMENT}

This article has been prepared within the research project VEGA No. 1/0279/19 "Model approaches to increase performance and competitiveness in the European area in the context of sustainable development". 


\section{REFERENCES}

1. Afonasova, M. A., Panfilova, E. E., Galichkina, M. A., \& Slusarczyk, B. (2019). Digitalization in economy and innovation: The effect on social and economic processes. Polish Journal of Management Studies, 19(2), 22-32. Retrieved from http://yadda.icm.edu.pl/ yadda/element/bwmeta1.element. baztech-bfeca0b5-4e44-4dd5b77d-4ac9d016da8d

2. Andrijauskiene, M., \& Dumčiuvienè, D. (2019). Inward foreign direct investment and national innovative capacity. Inzinerine Ekonomika-Engineering Economics, 30(3), 339-348. http://dx.doi.org/10.5755/j01. ee.30.3.22832

3. Balcerzak, A. P. (2020). Quality of institutions in the European Union countries. Application of TOPSIS based on entropy measure for objective weighting. Acta Polytechnica Hungarica, 17(1), 101-122. Retrieved from http:// acta.uni-obuda.hu//Balcerzak_98. pdf

4. Banelienè, R., Melnikas, B., Strazdas, R., \& Toločka, E. (2018). Innovation activities and the impact of investment in $\mathrm{R} \& \mathrm{D}$ on economic growth: Assessment and modelling. Terra Economicus, 16(4), 66-76. http://dx.doi. org/10.23683/2073-6606-2018-164-66-76

5. Belas, J., Dvorský, J., Strnad, Z., Valaskova, K., \& Çera, G. (2019). Improvement of the quality of business environment model: Case of the SME segment. Inzinerine Ekonomika-Engineering Economics, 30(5), 601-611. http://dx.doi.org/10.5755/j01. ee.30.5.24490

6. Bistrova, J., \& Lace, N. (2016). Effect of innovation on the EU member-countries economic development. Paper presented at $9^{\text {th }}$ International Scientific Conference: Business and Management 2016. Vilnius, Lithuania. http://dx.doi. org/10.3846/bm.2016.56

7. Boly, V., Morel, L., Assielou, N. G., \& Camargo, M. (2014). Evaluating innovative processes in French firms: Methodological proposition for firm innovation capacity evaluation. Research Policy, 43(3), 608-622. https://doi.org/10.1016/j. respol.2013.09.005

8. Brożek, K. (2018). Impact of selected determinants of innovation on the economic growth of the Visegrad group countries. $17^{\text {th }}$ International Scientific Conference on Hradec Economic Days, 9(1), 101111. Retrieved from https:// digilib.uhk.cz/bitstream/ handle/20.500.12603/89/ BRO $\%$ C5\%BBEK. pdf? sequence $=1$ \&isAllowed $=y$

9. Ciocanel, A. B., \& Pavalescu, F. M. (2015). Innovation and Competitiveness in European Context. Procedia Economics and Finance, 32, 728-737. https://doi.org/10.1016/S22125671(15)01455-0

10. Dobrota, C. E., Marcu, N., Siminica, M., \& Netoiu, L. M. (2019). Disparities, gaps and evolution trends of innovation, as a vector of economic development, in the countries of the European Union. Romanian Journal of Economic Forecasting, 22(4), 174-184. Retrieved from http://www.ipe.ro/rjef/rjef4_19/ rjef4_19p174-184.pdf

11. European Commission. (2015). The 2030 Agenda for Sustainable Development. Retrieved from https://ec.europa.eu/environment/ sustainable-development/SDGs/ index_en.htm

12. European Patent Office. (2019). European Patent Register. Retrieved from https://www.epo. org/index.html

13. Eurostat. (2019). Your key to European statistics. Retrieved from https://ec.europa.eu/eurostat/ home

14. Galindo-Martin, M. A., MendezPicazo, M. T., \& CastanoMartinez, M. S. (2019). The role of innovation and institutions in entrepreneurship and economic growth in two groups of countries. International Journal of Entrepreneurial Behavior \& Research, 26(3), 485-502. https://doi.org/10.1108/IJEBR-06-2019-0336

15. Grabara, J. (2019). Sustainable development - never fulfilled dream. Quality - Access to Success, 20(1), 565-570

16. Greene, W. H. (2003). Econometric Analysis (4th ed). New Jersey: Prentice-Hall.

17. Grodzicki, T. (2018). Fostering Sustainable Industry, Innovation and Infrastructure as a Part of Sustainable Development Agenda in the EU Countries: Spatial Analysis. In Challenging the status quo in management and economics: Strategica International Academic Conference, Sixth Edition, Bucharest, Romania, October 11 12 (pp. 130-141). Retrieved from https://www.researchgate.net/ publication/330737561_Fostering_Sustainable_Industry_Innovation_and_Infrastructure_as_a_ Part_of_Sustainable_Development_Agenda_in_the_EU_Countries_Spatial_Analysis

18. Hadad, S. (2015). Analytic hierarchy process analysis for choosing a corporate social entrepreneurship strategy. Management \& Marketing, 10(3), 185-207. https://doi.org/10.1515/ mmcks-2015-0014

19. Halkos, G., \& Skouloudis, A. (2018). Corporate social responsibility and innovative capacity: Intersection in a macro-level perspective. Journal of Cleaner Production, 182, 291300. https://doi.org/10.1016/j. jclepro.2018.02.022

20. Haseeb, M., Kot, S., Hussain, H. I., \& Jermsittiparsert, K. (2019). Impact of economic growth, environmental pollution, and energy consumption on health expenditure and $R \& D$ expenditure of ASEAN countries. Energies, 12(19), 1-20. https://doi. org/10.3390/en12193598

21. Hilkevics, S., \& Hilkevica, G. (2017). New information technologies use for Latvian stock companies financial health 
evaluation. Entrepreneurship and Sustainability Issues, 5(2), 178189. https://doi.org/10.9770/ jesi.2017.5.2(1)

22. Ivanova, E., \& Cepel, M. (2018). The impact of innovation performance on the competitiveness of the Visegrad 4 countries. Journal of Competitiveness, 10(1), 5472. https://doi.org/10.7441/ joc.2018.01.04

23. Janoskova, K., \& Kral, P. (2019). An in-depth analysis of the Summary Innovation Index in the V4 countries. Journal of Competitiveness, 11(2), 6883. https://doi.org/10.7441/ joc.2019.02.05

24. Kasa, R. (2015). Approximating innovation potential with neurofuzzy robust model. Investigaciones Europeas de Dirección y Economía de la Empresa, 21(1), 35-46. https://doi. org/10.1016/j.iedee.2014.02.001

25. Kaynak, S., Altuntas, S., \& Dereli, T. (2017). Comparing the innovation performance of EU candidate countries: an entropybased TOPSIS approach. Economic Research-Ekonomska Istrazivanja, 30(1), 31-54. https://doi.org/10.108 0/1331677X.2016.1265895

26. Kowalska, A., Kovarnik, J., Hamplova, E., \& Prazak, P. (2018). The Selected topics for comparison in Visegrad four Countries. Economies, 6(3), 1-15. https://doi. org/10.3390/economies6030050

27. Maharramov, A., Sariyev, K., Shamilova, H., \& Rasulova, M. (2018). Impact of applicable scientific innovations on the economic growth. In $6^{\text {th }}$ International Conference on Control and Optimization with Industrial Applications (COIA) (pp. 205-207).

28. Mihai, M., \& Titan, E. (2014). Education and innovation in the context of economies globalization. Procedia Economics and Finance, 15, 1042-1046. https://doi.org/10.1016/S22125671(14)00667-4

29. Proksch, D., Haberstroh, M. M., \& Pinkwart, A. (2017). Increasing the national innovative capacity:
Identifying the pathways to success using a comparative method. Technological Forecasting and Social Change, 116, 256-270. https://doi.org/10.1016/j.techfore.2016.10.009

30. Pukala, R., Sira, E., \& Vavrek, R. (2018). Risk management and financing among start-ups. Marketing and Management of Innovations, 3, 153-161. http://doi. org/10.21272/mmi.2018.3-13

31. Que, J., \& Zhang, X. (2018). The role of foreign and domestic venture capital in innovation: evidence from China. Accounting \& Finance, 60(1), 1077-1110. https://doi.org/10.1111/acfi.12401

32. Raghuapathi, V., \& Raghupathi, W. (2017). Innovation at county-level: Association between economic development and patents. Journal of Innovation and Entrepreneurship, 6(4), 1-20. http://dx.doi. org/10.1186/s13731-017-0065-0

33. Rajnoha, R., Lesnikova, P., Stefko, R., Schmidtova, J., \& Formanek, I. (2019). Transformations in strategic business planning in the context of sustainability and business goals setting. Transformations in Business \& Economics, 18(2), 44-66. Retrieved from http://www.transformations. knf.vu.lt/47/rp47.pdf

34. Risso, W. A., \& Carrera, E. J. S. (2019). On the impact of innovation and inequality in economic growth. Economics of Innovation and New Technology, 28(1), 64-81. http://doi.org/10.108 0/10438599.2018.1429534

35. Sidorova, E. (2018). The innovation development of the BRICS countries: Preconditions and prospects for cooperation. International Organizations Research Journal, 13(1), 34-50. http://doi.org/10.17323/19967845-2018-01-02

36. Tomaszewski, M., \& Świadek, A. (2017). The impact of the economic conditions on the innovation activity of the companies from selected Balkan states. Economic ResearchEkonomska Istrazivanja, 30(1), 1896-1913. https://doi.org/10.1080 /1331677X.2017.1398099
37. World Bank. (2019). World Bank Open Data. Retrieved from https:// data.worldbank.org/

38. Wu, J., Ma, Z., \& Zhuo, S. (2017). Enhancing national innovative capacity: The impact of hightech international trade and inward foreign direct investment. International Business Review, 26(3), 502-514. https://doi. org/10.1016/j.ibusrev.2016.11.001

39. Yildirim, D. C., \& Arun, K. (2019). Effects of economic clusters, FDI and R\&D on innovation: developing countries in European Monetary Union example. International Journal of Innovation, 7(2), 236-251. https:// doi.org/10.5585/iji.v7i2.264

40. Zang, L., Xiong, F., Lao, X., \& Gao, Y. (2018). Does governance efficiency matter for national innovative capacity? One tale from different countries. Technology Analysis \& Strategic Management, 31(2), 239-252. https://doi.org/10.1080/09537325. 2018.1493450

41. Zeng, D. Z. (2017). Measuring the Effectiveness of the Chinese Innovation System: A Global Value Chain Approach. International Journal of Innovation Studies, 1(1), 57-71. https://doi. org/10.3724/SP.J.1440.101005

42. Zhao, J. X. (2018). An empirical study on the impact of technological innovation on economic growth-taking Shandong Province as an example. Proceedings of the $4^{\text {th }}$ Annual International Conference on Social Science and Contemporary Humanity Development (SSCHD) (pp. 454-457). https://doi. org/10.2991/sschd-18.2019.82 